\title{
A Method and Apparatus for Determining the Ignition Characteristics of Plastics
}

\author{
By Nicholas P. Setchkin
}

\begin{abstract}
A method for the determination of the ignition temperatures of plastics is described. It is suitable for the determination of flash-, as well as self- or autogenous-ignition temperatures. The flash temperature is that temperature at which the specimen yields combustible gases ignitible by a flame. The self-ignition temperature is the lowest temperature of supplied air, under optimum conditions of air flow, at which a reaction of the specimen, or of its. decomposition products, begins and is self-accelerated to the state of combustion. The described method generally results in lower and more consistently reproducible values of the self-ignition temperature than those reported by several other investigators.
\end{abstract}

Twenty-seven different "specimens of plastics, covering a wide range in characteristics, were tested by the method described.

\section{Introduction}

An apparatus and method for determining the ignition characteristics and behavior of plastics under well-controlled conditions have been developed at this Bureau from a consideration of the fundamental principles of ignition. Twenty-seven specimens of plasties with a wide range of physical properties and ignition characteristics were tested in order to determine the validity of the method and the adaptability of the apparatus.

It is doubtful whether methods heretofore proposed for measuring the ignition temperatures of plastics actually indicate the lowest ignition temperatures. Stokes and Weber $[1]^{1}$ measured the ignitability of plastics by bringing the specimen into contact with a heated porcelain rod just removed from a furnace, or with a molten lead bath heated in a furnace to the required temperature. The estimated temperature of the porcelain rod or of the lead, at which the specimen "instantly" ignited, was accepted by them as the ignition temperature. Delmonte and Azam [2] later substituted molten sodium hydroxide for the lead bath. In their tests, the bath temperature at which a plastic specimen ignited instantly, or within $10 \mathrm{sec}$, when in contact with the bath was considered as the ignition temperature of the material. More recently, Schoenborn and Weaver

\footnotetext{
${ }^{1}$ Figures in brackets indicate the literature references at the end of this paper.
}

Method for Ignition of Plastics
[3] used a method in which the specimen was: placed in a furnace heated to a temperature definitely above the ignition temperature of the material. The ignition temperature was defined by the estimated surface temperature of the specimen at the instant of the ignition and was called by them the "apparent ignition temperature." The estimate of this temperature was made by analytical extrapolation of temperatures measured within the specimen, to yield those at the surface at the moment of ignition.

In this method, observation of the temperatures: and the extrapolation from them to the actual locus of ignition did not give consistent and reproducible results for a given material [4].

Gale, Stewart, and others $[5,6]$ used an electrically heated coil around the plastic specimen and observed the time lag required for gases developed. from the specimen to be ignited by spark plugs. A so-called ignition temperature, (which in reality is the "flash temperature," as defined in section II) was determined by them from a "conversion curve." This curve was developed by measuring with a thermocouple the temperature at the edge of the specimen and observing the time lag for ignition. This time lag was composed of two superimposed periods; one of which was the time required to heat the coil, and the other was the time required to heat the specimen and to produce sufficient combustible gases to be ignited by the 
spark plug. These superimposed lags are related to two entirely different phenomena, therefore the range of the ignition temperature, which indicates the accuracy of their determination (shown in table 3 of [6]), varied for a given plastic from $55^{\circ}$ to $175^{\circ} \mathrm{C}$, with an average of $127^{\circ} \mathrm{C}$.

Most of the results obtained by these and similar methods differ materially in their numerical values, as well as in their consistency and reproducibility, because they were obtained under entirely different and noncomparable conditions that were unsuited for the determination of the lowest ignition temperatures. The main purpose of the studies at this Bureau was to develop a sound relation between the ignition phenomena and controllable conditions of test; and on this basis to determine the lowest values of the ignition temperatures and any other characteristics that may affect the fire hazards and therefore safety regulations.

\section{Theoretical Considerations}

Several years ago a constant-air-temperature method for measuring the ignition temperatures of solids, based upon the principles of ignition stated below, was developed at this Bureau. In this method, successive specimens of the material were heated in air at different constant temperatures until one of them ignited. The same method was found applicable for plastics with a wide range of thermophysical characteristics.

The following definitions of ignition characteristics of materials were employed in the development of the test method. The "flash temperature" is the initial temperature of the air passing around the specimen, at which a sufficient amount of combustible gas is developed to be ignited by an external heat source such as a flame, spark, or hot surface. The "self-ignition temperature" is the initial air temperature, at which, in the absence of an ignition source, ignition occurs of itself, as indicated by an explosion, flame, or sustained glow.

It is well known that the ignition of most combustible materials, excepting those such as cellulose nitrate that contain oxygen in an active form, can be initiated only in the presence of sufficient amounts of oxygen. Before ignition occurs, oxygen must participate in an oxidation reaction with the solid or liquid material, with the vapor, or with gases evolved at elevated temperatures from the decomposition of the material. In order to promote this reaction, the products of oxidation must be removed continuously and fresh portions of oxygen supplied. Actual ignition, as indicated by a flame, may result either from the accelerated exothermic reaction of vaporized or gaseous components of the material with oxygen, or through the self-heating within the solid or liquid material, which eventually leads to sustained glow of some of the nongaseous components or of the carbonized residue.

On the above basis, ignition can be defined as a self-perpetuating exothermic reaction that is initiated at the temperature of incipient oxidation, and that increases the temperature of the reactants above the initial air temperature until an explosion, flame, or sustained glow occurs. Because of the temperature differences existing within the reacting masses and between them and the surrounding walls, a certain part of the generated heat is dissipated to masses at lower temperatures. Also, some heat is carried away by the passing air and by the products of oxidation. The rate of the oxidation reaction, as well as the rate of its acceleration to self-ignition, is dependent upon the rate of heat dissipation. This will be evident from the following discussion of the time-temperature curves drawn in figure 1 for different initial temperatures.

If an incombustible material be subjected to heating at the constant-air-temperature, $t_{0}$, the temperature of the material will eventually be practically equal to that of the surrounding air, e. g. after the time lag $l_{0}$. This lag depends upon the mass, heat conductivity, and specific heat of the material and upon the initial temperature difference between the air and the material. At relatively low air temperatures, a similar behavior will be observed with conbustible materials. However, at a higher air temperature $t_{1}$, which is higher than the observed temperature of incipient oxidation $t_{x}$, the material begins to oxidize with the generation of heat, and beyond the point $t_{x}$, the temperature of the material increases more rapidly than it would in the normal process of heating without oxidation. The temperature of the material continues to increase and eventually exceeds the air temperature, $t_{1}$. The rate of temperature increase depends upon the difference between the rates of heat generation and of heat 


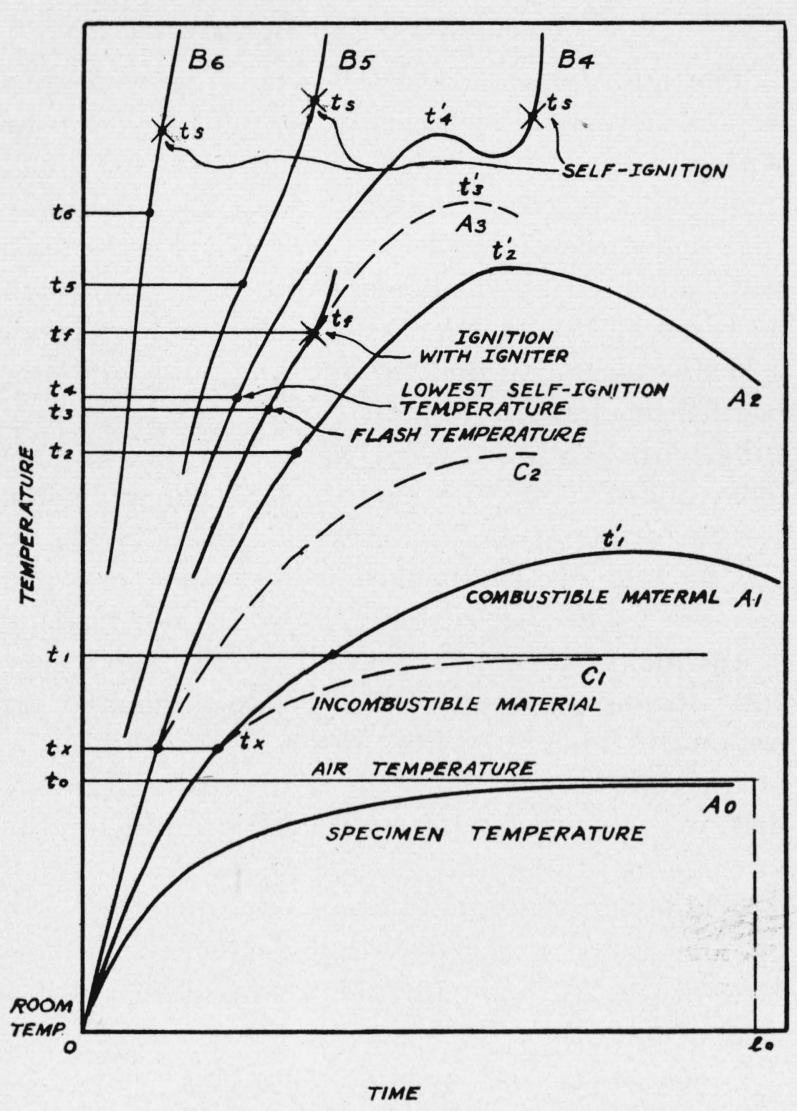

Figure 1. Theoretical time-temperature curves for heating and ignition of materials.

Curves $A_{0}, A_{1}, A_{2}$, and $A_{3}$ for nonignition reaction at air temperatures $t_{0}, t_{1}, t_{2}$, and $t_{3}$; curves $R_{4}, R_{3}$, and $R_{6}$ for self-ignition reaction at air temperatures $t_{4}, t_{5}$, and $t_{6}$; curves $A_{0}, C_{1}$, and $C_{2}$ for heating of noncombustible materials at air temperatures $t_{0}, t_{1}$, and $t_{2}$.

dissipation. The rate of heat generation depends mainly upon the temperatures of the specimen and of the air, the supply of air, the concentration of oxygen in the reacting gases, and the chemical and physical characteristics of the material. The rate of heat dissipation depends in part upon the temperature difference between the reacting mass and their surroundings, and in part upon the rate of flow of the air. An insufficient air flow leads to contamination of the air by the products of oxidation and depletes the oxygen supply. This condition hinders oxidation and lowers or stops entirely the exothermic reaction. On the other hand, an excessive air flow carries away a large amount of the generated heat and thus lessens or interrupts the exothermic reaction. The optimum rate of air flow, at which a relatively favorable rate of reaction is reached, must be estab- lished experimentally for each type of material. The temperature of the material usually continues to rise until the rate of heat generation equals the rate of heat dissipation, e. g. at a point corresponding to the maximum temperature $t^{\prime}{ }_{1}$, indicated by a thermocouple $T h_{3}$ (fig. 2) in or on the specimen. This process is often accompanied by the evolution of vapor gas, which at this particular stage may not be ignitible, either by itself or by an igniter, because of its low rate of evolution and consequent dilution with air.

At some other constant-air-temperature such as $t_{2}$, the material may self-heat by oxidation to a higher temperature such as $t_{2}^{\prime}$. However, during self-heating, starting at an air temperature of $t_{3}$, the concentration of evolved combustible gases or vapors may become favorable to their ignition by the pilot flame at a particular temperature $t_{f}$, which is often below the maximum temperature $t^{\prime}{ }_{2}$ of the previous case, where the ignition could not have occurred. The air temperature $t_{3}$ in this case is called the flash temperature. In the absence of the ignition flame, self-heating may proceed to the corresponding maximum temperature $t^{\prime}{ }_{3}$ without selfignition. Owing to these factors, regularly observed with many materials, the instantaneous temperature $t_{f}$ has no important significance, even if it could be determined accurately, because this temperature, as well as the rate of heat generation and the rate of gas development and dilution, depend mainly upon the initial temperature and velocity of the air passing around the specimen.

In many cases, it was observed that the rate of the exothermic reaction was reduced beyond a temperature peak such as $t^{\prime}{ }_{4}$ by excessive contamination of the air with the decomposition products, by cooling caused by a high rate of air flow, by some endothermic reaction, or by reduction of the available reactive material. With proper adjustment of air flow (which reduces the rate of temperature rise near the point $t^{\prime}{ }_{4}$ ), it is possible for the rate of oxidation to be accelerated again to the self-ignition of gases at a higher temperature, such as $t_{s}$. This temperature, $t_{s}$, like the temperature $t_{f}$, has no important significance in relation to the ignition characteristics, because it depends upon both the initial air temperature $t_{4}$ and the rate of air flow. Therefore, the temperature $t_{4}$ of the air, at which with the optimum air flow and in the absence of an igni- 
tion source, ignition occurs is called the selfignition temperature of the material.

At higher initial air temperatures such as $t_{5}$ and $t_{6}$, self-ignition occurs more readily, and the ignition lag rapidly diminishes to a fraction of a second with continued increase in the initial temperature. The ignition lag for the lowest self-ignition temperature $\left(t_{4}\right)$ may vary from a few minutes to a few hours, depending upon the difference between the rates of heat generation and heat dissipation, which is affected by the size of the specimen, as well as by the thermo-chemical and physical properties of the material.

The evidence of self-ignition is usually observed in the form of an explosion, flame, or sustained glow. In some plastic materials the ignition temperatures corresponding to the various types of behavior differ appreciably. The self-ignition accompanied by explosion or flame usually occurs at comparatively high initial air temperatures; however, slow decomposition and carbonization of some plastics leads to glow of the corners and edges at lower temperatures. Therefore, a secondary term, "self-ignition by glow", is proposed. The self-sustained glow may in some cases, with proper air flow, lead to ignition of the combustible gases.

The foregoing considerations indicate that "instant" ignition of the material in contact with a hot surface, as specified by some of the early methods, occurs at much higher temperatures than are observed with the constant-air-temperature method. Therefore, as explained in section $\mathrm{V}, 5$ this hot-surface ignition temperature does not represent the true fire hazard of the materials.

\section{Ignition Apparatus}

The apparatus for the determination of the ignition characteristics of plastics was developed on the basis of the fundamentals of ignition phenomena discussed above. In the construction of the apparatus, particular attention was given to the following major requirements:

(a) The temperature of the air passing the specimen should be uniform and constant. (b) The air flow should be steady and controllable. (c) The specimen should be in a stream of air of known temperature; be visible from the outside; and be easily removable.

\section{Construction of the Apparatus}

The ignition apparatus shown in figure 2 consists of a vertical electrically heated furnace tube with a 4 -in. $(10 \mathrm{~cm})$ bore, $8 \% \frac{3}{4}$ in. $(22 \mathrm{~cm})$ long, made of refractory material such as a ceramic that will withstand at least $1,000^{\circ} \mathrm{C}$. The furnace tube is heated by electric current passing through 50 turns of No. 16 B\&S gage nichrome wire in an asbestos sleeve wound around the tube and imbedded in alundum cement. The inner refactory tube with a 3 -in. (7.6-cm) bore, $8 \frac{3 / 4}{4}$ in. $(22 \mathrm{~cm})$ long, about $1 / 8$ in. $(0.3 \mathrm{~cm})$ thick is placed inside of the furnace tube and rests on small blocks in the bottom of the furnace. The space between the two tubes is used for circulation and heating of the air, admitted tangentially to the refractory tube through a copper tube. The preheated air enters the inner tube from below. The top of the latter tube is covered with a divided refractory disk with an opening for observation and for the passage of smoke and gases. If desired, a small gas flame can be lighted above the opening. An opening fitted width disk is provided at the bottom of the furnace for the removal of residue that accumulates during the tests.

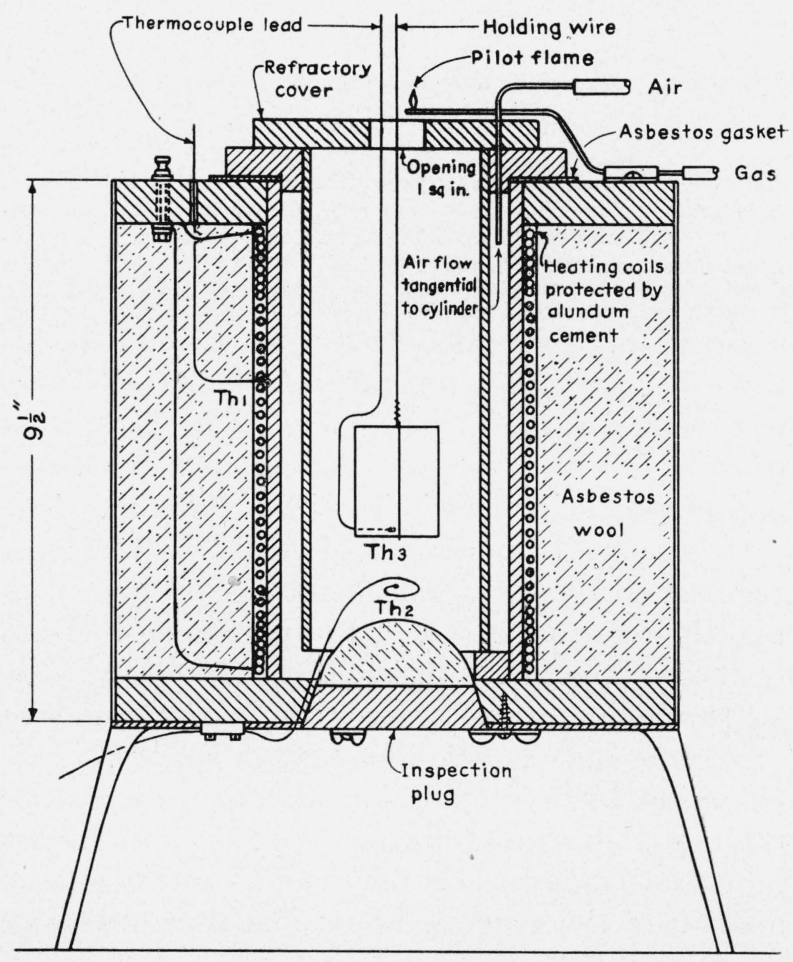

Figure 2. Ignition apparatus for solids.

$T h_{1}$-thermocouple on outer wall, $T h_{2}$-thermocouple in air stream, $T h_{3}$-thermocouple in or on the specimen. 


\section{Thermocouples}

The temperature of air rising in the inner tube is indicated by thermocouple $T h_{2}$ placed below the specimen. It is advisable to shield this thermocouple against heat radiated from the specimen during intense oxidation reactions, especially if the thermocouple is near the specimen. However, since the temperature of the air supplied to the chamber remains substantially constant, any momentary increase of temperature shown by thermocouple $T h_{2}$ during intense oxidation reactions is not important. The temperature of the air in the inner tube is maintained constant by current supplied through a variac connected in series with the heating coils. Adjustments of the current are preferably made by reference to the readings of thermocouple $T h_{1}$ behind the coils, rather than by reference to thermocouple $T h_{2}$ (below the specimen), which always has a somewhat delayed response to current changes.

A third thermocouple, $T h_{3}$, is either attached to the surface or inserted within the lower part of the specimen. The rate of temperature rise in the specimen, indicated by this thermocouple is generally related to the rate of the oxidation reaction. The exact location of thermocouple $T h_{3}$ in the specimen is of minor importance because of the uncertainty as to the locus of ignition, but since ignition is usually initiated at the surface of the lower part of the specimen, it is desirable to locate the thermocouple junction in this region. A small bare thermocouple junction is used because of its sensitivity to small variations in temperature.

\section{Size of Specimen}

The size of specimen is varied with type and availability of the material. The standard size usually specified for incombustibility tests [7] is $1 \frac{1}{2}$ in. $(3.8 \mathrm{~cm})$ wide by 2 in. $(5 \mathrm{~cm})$ long, by the thickness of specimen, which should not exceed $1 \frac{1}{2}$ in. $(3.8 \mathrm{~cm})$. However, for determining the ignition characteristics of plastics, the preferred size of specimen is $3 / 4$ in. $(1.9 \mathrm{~cm})$ by $3 / 4$ in. $(1.9 \mathrm{~cm})$ by $3 / .9 \mathrm{~cm}) \cdot$ by about $1 / 2 \mathrm{in} .(1.3 \mathrm{~cm})$ thick. For materials made in thin plates, the specimen consists of a few plates with a total thickness of about $1 / 2$ in. $(1.3 \mathrm{~cm})$ tightly bound together by wire. For materials submitted in the form of small pieces, chips, filings or powder, and for those that melt or bubble at temperatures below ignition, a wire screen basket or a porcelain crucible with a capacity of about $0.5 \mathrm{in}^{3}(8 \mathrm{ml})$ is used. Within these limits the ignition temperature is not appreciably affected by the size; however, the ignition time-lag varies perceptibly with the size. Small specimens of those materials that develop insignificant amounts of combustible gases, yield less consistent results for the lowest ignition temperature than do those of larger size.

\section{Suspension of Specimen}

The arrangement for holding the specimen is important, especially for materials whose physical state changes at temperatures below the ignition point. Materials that remain rigid during the test can be suspended on a wire; those which melt to a viscous mass and which bubble can be held in a wire-screen basket; and those which melt to a liquid state, like methyl methacrylate, polystyrene, and others; or those which foam like cellulose acetate, can be placed in a preheated porcelain crucible. Owing to a large gradient in the temperature of the air in the upper portion of the inner tube, the specimen should be placed in the region $4 \frac{1}{2}$ to $6 \frac{1}{2}$ in. (11 to $16 \mathrm{~cm}$ ) from the top, where the air temperature around the specimen is uniform within $\pm 3 \mathrm{deg}$. C.

\section{Test Procedure}

\section{Rising-Temperature Method}

In tests conducted in accordance with the risingtemperature method $[7,8]$, the specimen is placed in the apparatus at a comparatively low temperature. In the method described in reference [8] the temperature of the apparatus is then raised at the rate of $500 \mathrm{deg} \mathrm{C}$ per hour until ignition occurs by itself, or by an igniter, or until $750^{\circ} \mathrm{C}$ is reached. If at this temperature ignition has not occurred, the material is considered incombustible. Some materials heated in this manner decompose or carbonize slowly without ignition of the material of the carbonized residue at temperatures higher than those obtained with the constant-temperature method. Therefore, this method is not always suitable for exact determination of the flash and self-ignition temperatures. However, it can be used to indicate the approximate ignition temperatures by the evidence of appreciable self-heating in the region of 
the ignition temperature, even though actual ignition is not observed. More precise determinations of the flash and self-ignition temperatures can be made by the constant-temperature method described below.

\section{Constant-Temperature Method}

When the temperature of the air passing through the inner tube with a selected rate of flow has become constant at a selected value, a specimen of the material to be subjected to test is placed in the middle of the inner tube together with a thermocouple, $T h_{3}$, either attached to the surface or inserted within the specimen. The air temperature may fall slightly below the initial value, owing to the presence of the cold specimen, but within a few minutes it returns to the initial value. The uniformity of the air temperature around the specimen is quite sensitive to the velocity of air flow, especially when the size of the specimen is small. Fluctuations in temperature caused by excessive turbulence can be avoided by keeping the air velocity around the specimen at about $15 \mathrm{ft} / \mathrm{min}$ ( $5 \mathrm{~m} / \mathrm{min}$ ), particularly during the preliminary tests. However, a favorable rate of air flow is usually fixed in accordance with the trend of the exothermic reaction. The rate is generally varied from 3 to $40 \mathrm{ft} / \mathrm{min}$ ( 1 to $13 \mathrm{~m} / \mathrm{min}$ ), depending upon the material tested. A close selection of the optimum rate of air flow can be made with a series of tests in the region of the lowest ignition temperature, conducted with various constant rates of air flow.

\section{Test Results}

\section{Test Materials}

To aid in the development of an ignition apparatus and a suitable test method, 27 samples of plastics were employed. These plastics, with a wide range of physical and ignition characteristics, were divided into two basic groups: (a) thermoplastic, and (b) thermosetting. Most of the latter group were reinforced with paper, asbestos, cotton, or glass fabric. A general description of these plastics is given in table 1 .

\section{Ignition Characteristics of Thermoplastic Materials}

The basic ignition characteristics of some of these thermoplastics, including results of hot-plate tests, are given in table 2 . The plastics of the thermoplastic group, with the exception of polytetrafluoroethylene, were transparent, and the appearance of small bubbles was observed at an early stage of decomposition at comparatively low temperatures. The appearance of bubbles and the swelling of the material increased rapidly with an increase in temperature, particularly with cellulose nitrate, which suddenly, without preliminary self-heating, ignited with an explosion or burst of flame. The bubbling of cellulose acetate increased during the melting to produce a foam. Methacrylate and polystyrene melted to thin liquids and boiled similarly to water, hence these materials were held in a crucible. The heavy foams of vinyl chloride-acetate yielded a hollow porous carbonized shell, inside of which the glow was usually initiated. This material was held in a wire-screen cup.

Cellulose nitrate, a material containing active oxygen, can be ignited without air flow, and therefore its lowest self-ignition temperature varied considerably with the method of heating and the impurities present. Specimens of this plastic in the $1 / 2-$ by $3 / 4$ - by $3 / 4$-in $(1.3$ by 1.9 by $1.9 \mathrm{~cm}$ ) size, heated for $6 \mathrm{hr}$ under selected conditions with normal air flow, about $15 \mathrm{ft} / \mathrm{min}$, as found favorable in the preliminary tests of most of the plastics, were not ignited at an air temperature of $140^{\circ} \mathrm{C}$ and during this time were self-heated to only $4^{\circ} \mathrm{C}$ above the air temperature. During a test with an air temperature of $141^{\circ} \mathrm{C}$, the temperature of the specimen after $1 \mathrm{hr}$ and $54 \mathrm{~min}$ reached only $150^{\circ} \mathrm{C}$, when sudden decomposition and ignition occurred, as shown in figure 3 . The ignition lag rapidly diminished with rise in the initial air temperature, as the two curves in figure 4, drawn for different time scales, indicate. The lower curve represents the change in the ignition lag time for air temperatures from $141^{\circ}$ to $220^{\circ} \mathrm{C}$, and the upper curve, for air temperatures above $220^{\circ} \mathrm{C}$. With the air temperature at about $141^{\circ}$ $\mathrm{C}$, the ignition lag decreased at the rate of about $12 \mathrm{~min}$ per increase of $1 \mathrm{deg} \mathrm{C}$. On the other hand, at air temperatures above $250^{\circ} \mathrm{C}$, the ignition lag was shortened to a fraction of a minute. The ignition lag curves for other plastics are shown in figure 5. In order to produce ignition within $10 \mathrm{sec}$, as specified in some methods, the air temperature had to be above $370^{\circ} \mathrm{C}$, and a 1-sec lag could be obtained only at air temperatures above $550^{\circ} \mathrm{C}$. Therefore, an ignition temperature de- 
TABLE 1. Identification of plastics

\begin{tabular}{|c|c|c|c|}
\hline Type & Manufacturer or source & $\begin{array}{l}\text { Thick- } \\
\text { ness }\end{array}$ & Name or description \\
\hline \multicolumn{4}{|c|}{ THERMOPLASTIC MATERIALS } \\
\hline $\begin{array}{l}\text { Cellulose nitrate. } \\
\text { (a) } \\
\text { (b) } \\
\text { Vinyl chlose acetate. } \\
\text { (a) } \\
\text { (b) } \\
\text { Polystyrene-acetate: } \\
\text { Polytetrafluoroethylene }\end{array}$ & $\begin{array}{l}\text { Celanese Corp. of America. } \\
\text { Monsanto Chemical Co. } \\
\text { E. I. du Pont de Nemours \& Co., Inc. } \\
\text { Rohm \& Haas Co } \\
\text { Bakelite Corp } \\
\text { Plax Corp. do } \\
\text { E. I. du Pont de Nemours \& Co., Inc... }\end{array}$ & $\begin{array}{c}\text { in. } \\
1 / 16 \\
1 / 8 \\
1 / 8 \\
1 / 8 \\
\\
1 / 8 \\
1 / 4 \\
1 / 4 \\
3 / 8\end{array}$ & $\begin{array}{l}\text { Celluloid, transparent. } \\
\text { Clear, special optical grade. } \\
\text { HC-202. } \\
\text { Plexiglas. } \\
\text { Clear, VS-1310. } \\
\text { Do. } \\
\text { Clear, Type M, compression molded. } \\
\text { White plate. }\end{array}$ \\
\hline \multicolumn{4}{|c|}{ THERMOSETTING MATERIALS } \\
\hline $\begin{array}{l}\text { Phenolic group: } \\
\text { Paper Laminate: } \\
\text { (a) } \\
\text { (b) } \\
\text { Cotton-cloth laminate } \\
\text { Asbestos-cloth laminate } \\
\text { (a) } \\
\text { (b) } \\
\text { Melamine group: } \\
\text { Mineral-filled melamine } \\
\text { Cotton-cloth laminate } \\
\text { Glass-cloth laminate: } \\
\text { (a) } \\
\text { (b) } \\
\text { Polyester group: } \\
\text { Glass-cloth laminate: } \\
\text { (a) } \\
\text { (b) } \\
\text { (c) } \\
\text { (d) } \\
\text { (e) } \\
\text { (f) } \\
\text { (g) } \\
\text { Silicone group: } \\
\text { Glass-cloth silicone: } \\
\text { (a) } \\
\text { (b) }\end{array}$ & 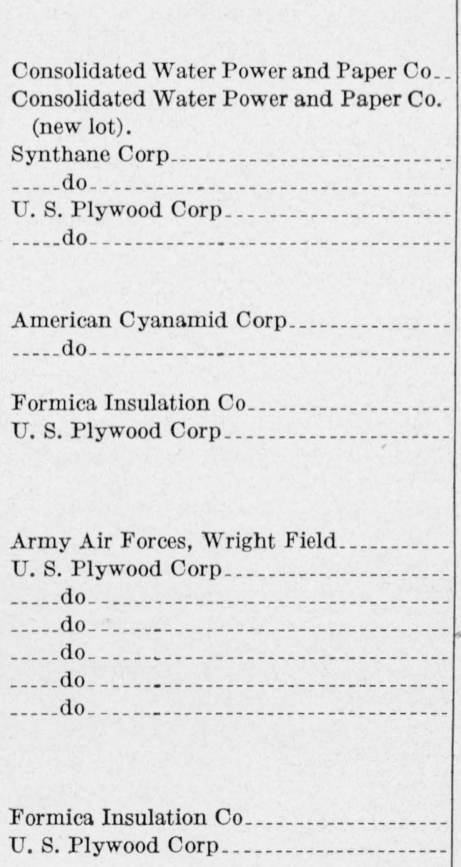 & $\begin{array}{l}1 / 8 \\
1 / 8 \\
1 / 8 \\
1 / 2 \\
1 / 8 \\
1 / 8\end{array}$ & $\begin{array}{l}\text { Cross laminated Mitscherlich paper: } 30 \text { percent } \\
\text { Bakelite phenolic resin. } \\
\text { Grade L, } 48 \text { percent Bakelite, BV-1112 resin. } \\
\text { Grade AA, } 47 \text { percent Bakelite, BV } 2427 \text { resin. } \\
6050 . \\
5013 . \\
592 \text {. } \\
\text { White plate. } \\
128 \text {, F F-55. } \\
\text { Not available. }\end{array}$ \\
\hline
\end{tabular}


TABLE 2. Ignition characteristics of plastics

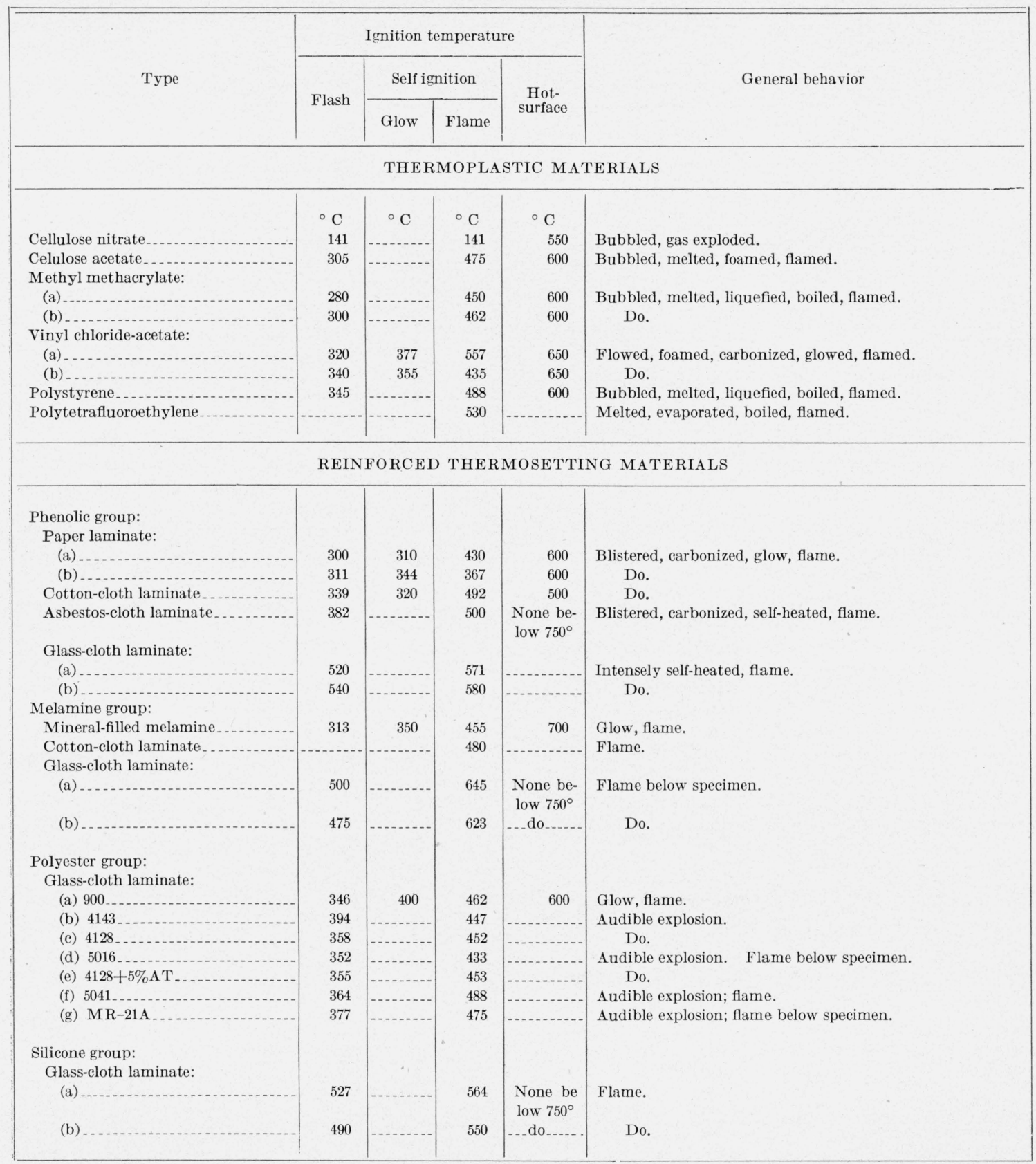


fined by the method that required a lag of from 1 to 10 sec was very much higher than the selfignition temperature defined by the present method and hence did not represent the true fire hazard.

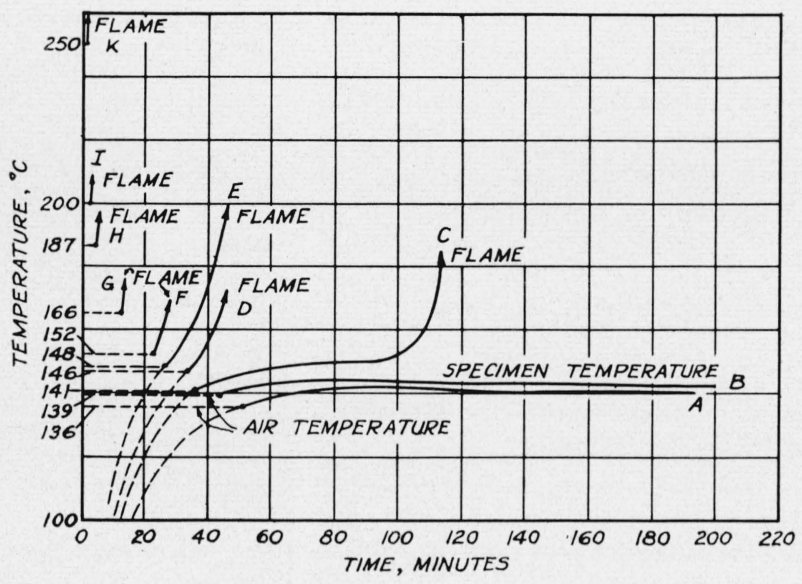

Figure 3. Time-temperature curves for cellulose nitrate.

Curves $A$ and $B$ for nonignition reaction; curves from $C$ to $K$ for self-ignition reaction. The lowest self-ignition temperature is $141^{\circ} \mathrm{C}$.

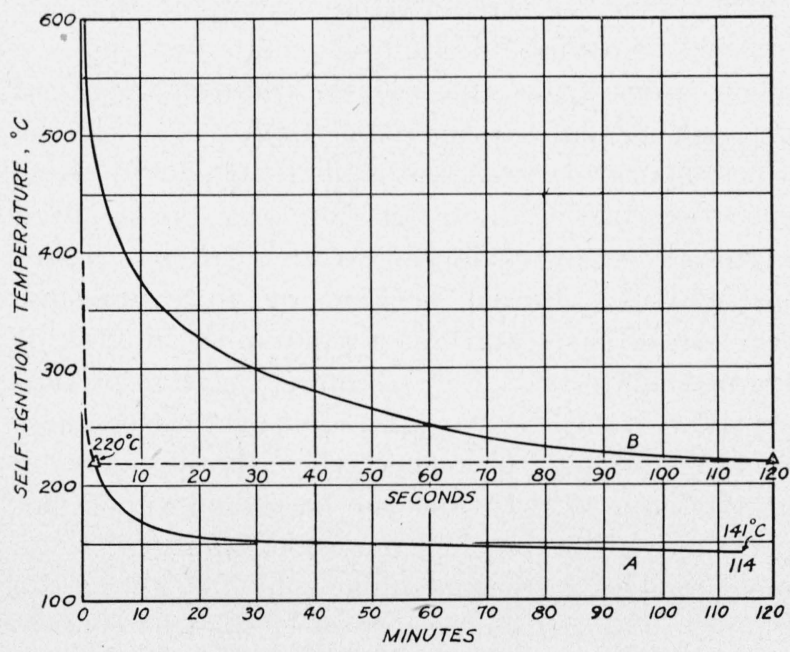

Figure 4. Ignition lag curves for cellulose nitrate.

Curve $A$ at air temperatures from $141^{\circ}$ to $220^{\circ} \mathrm{C}$ and curve $B$ from $220^{\circ}$ to $600^{\circ} \mathrm{C}$

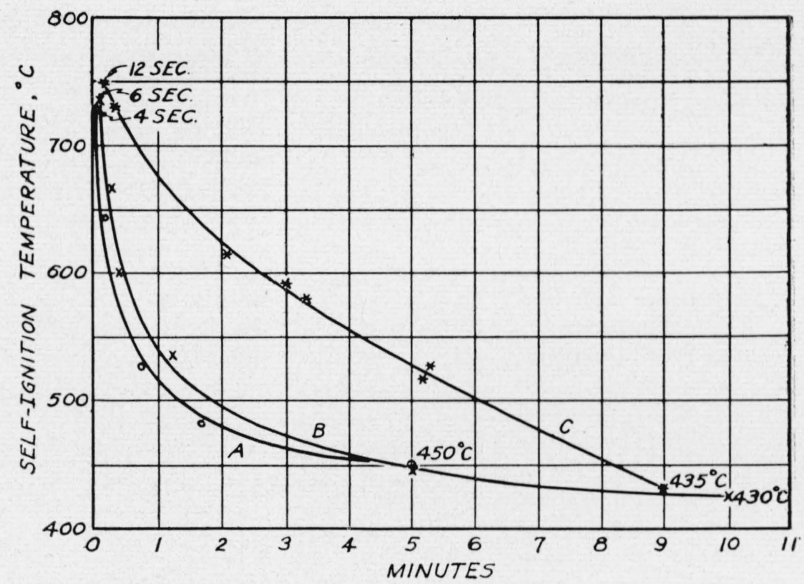

Figure 5. Ignition lag curves for plastics.

Curve $A$-methyl methacrylate (a); curve $B$-phenolic paper laminated; and $C$-vinyl chloride acetate.

A box of cellulose nitrate plastic triangles, separated by wrapping paper, was reported to have ignited after a 1-hr exposure to the sun in southern Texas. Specimens of material from the same source, about ${ }^{3 / 4}$ in. ${ }^{3}$ in volume, were subjected to tests in the ignition apparatus at the Bureau in a closed test tube without air circulation. During $72 \mathrm{hr}$ of heating, self-heating of the specimen was observed to be about $1 \mathrm{deg} \mathrm{C}$ at $105^{\circ} \mathrm{C}$, about $5 \mathrm{deg} \mathrm{C}$ at $135^{\circ} \mathrm{C}$, and the rise in temperature was only $6 \mathrm{deg} \mathrm{C}$ at $141^{\circ} \mathrm{C}$ after $6 \mathrm{hr}$ of heating. However, at a temperature of $142^{\circ} \mathrm{C}$, self-heating of about $6 \mathrm{deg} \mathrm{C}$ occurred during a $32-\mathrm{min}$ period, when the specimen burst into flame. These tests indicate that the temperature of incipient oxidation was about $105^{\circ} \mathrm{C}$, and the self-ignition temperature was approximately $142^{\circ} \mathrm{C}$. Triangles from the same lot, separated and covered by the original wrapping paper, were self-ignited after $3.5 \mathrm{hr}$ of heating at a temperature of $135^{\circ} \mathrm{C}$, the self-ignition temperature of the paper being about $235^{\circ} \mathrm{C}$.

Physical properties of the thermosetting materials, observed at different temperatures prior to ignition, are shown in table 3 . 
TABLE 3. Physical characteristics of thermosetting materials prior to ignition

\begin{tabular}{|c|c|c|c|c|c|c|}
\hline & \multirow{2}{*}{ Cellulose nitrate } & \multirow{2}{*}{ Cellulose acetate } & \multicolumn{2}{|c|}{ Methyl Methacrylate } & \multirow{2}{*}{$\begin{array}{l}\text { Vinyl Chloride } \\
\text { acetate }\end{array}$} & \multirow{2}{*}{ Polystyrene } \\
\hline & & & (a) & (b) & & \\
\hline & \multicolumn{6}{|c|}{ Temperature, ${ }^{\circ} \mathrm{C}$} \\
\hline $\begin{array}{l}\text { Appearance of bubbles.- } \\
\text { Loss of transparency.-.- } \\
\text { State prior to ignition.-. }\end{array}$ & $\begin{array}{l}105 \\
120 \\
\text { Soft }\end{array}$ & $\begin{array}{l}130 \\
150 \\
\text { Soft }\end{array}$ & $\begin{array}{l}150 \\
220 \\
\text { Liquid }\end{array}$ & $\begin{array}{l}200 \\
250 \\
\text { Liquid }\end{array}$ & $\begin{array}{l}160 \\
190 \\
\text { Spongy mass }\end{array}$ & $\begin{array}{l}160 . \\
200 . \\
\text { Viscous liquid. }\end{array}$ \\
\hline State prior to ignition... & \multicolumn{6}{|c|}{ Rise in temperature, ${ }^{\circ} \mathrm{C}$} \\
\hline $\begin{array}{l}\text { Self-heating of material } \\
\text { prior to ignition. }\end{array}$ & & & & & & None. \\
\hline $\begin{array}{l}\text { Self-heating of gases } \\
\text { above the molten } \\
\text { material. }\end{array}$ & None... & None... & Very high... & Very high... & Slight_.. & None. \\
\hline $\begin{array}{l}\text { Apparent cause of self- } \\
\text { ignition. }\end{array}$ & $\begin{array}{l}\text { Rapid decomposi- } \\
\text { tion. }\end{array}$ & $\begin{array}{l}\text { Self-flash of gases } \\
\text { from inflated } \\
\text { material. }\end{array}$ & $\begin{array}{l}\text { Self-heating of } \\
\text { gases above } \\
\text { molten metal. }\end{array}$ & $\begin{array}{l}\text { Self-heating of } \\
\text { gases above } \\
\text { moltenmaterial. }\end{array}$ & $\begin{array}{l}\text { Glow of carbon- } \\
\text { ized materials. }\end{array}$ & $\begin{array}{l}\text { Self-flash of gases in } \\
2 \mathrm{~d} \text { state of decom- } \\
\text { position. }\end{array}$ \\
\hline
\end{tabular}

The appearance of bubbles and loss of transparency of the plastics rapidly increased with the temperature and duration of exposure; therefore, the extents of these changes observed within the first hour have only relative significance. In cellulose acetate the bubbles increased mainly in size, in contrast with other plastics in which they increased greatly in number. The state prior to ignition varied with the type of plastic. Both cellulose nitrate and acetate plastics are soft just before ignition. However, near the ignition temperature, cellulose nitrate remains soft indefinitely, whereas cellulose acetate inflates, melts, and evaporates. Methyl methacrylate (fig.6) and polystyrene melted below their ignition temperatures and remained in a liquid state for an appreciable time until entirely evaporated without iginition. Vinyl chloride-acetate formed a spongy semi-soft shell inside of which a glow of carbonized material occurred. The self-heating of all of these materials (with the exception of vinyl chloride-acetate) prior to ignition varied from 10 to $40 \mathrm{deg} \mathrm{C}$ above the air temperature. Vinyl chloride-acetate self-heated considerably, owing apparently to oxidation and carbonization of the spongy mass. Very intense self-heating was observed only in the vapor above molten methyl methacrylate plastics, in that the wires holding the crucible became red hot. It is doubtful whether there was a catalytic effect of these heated wires to produce self-ignition, which usually occurred at an early stage of the reaction and before the wires became red hot. However, in the nonignition zones the red hot wires did not appear to stimulate ignition. Self-ignition of cellulose nitrate, indicated by a mild audible explosion, usually occurred very suddenly, apparently owing to rapid decomposition of the soft inflated material. Cellulose acetate was ignited when gases from the inflated material escaped through a local rupture into the hot air. If the air temperature was not sufficiently high, these gases escaped without ignition and the deflated material began to melt. Methyl methacrylates (a) and (b) ignited because of an exothermic reaction of gases and hot air above the molten or foamed material. For example, methyl methacrylate (a) and (b) was ignited at air temperatures of $450^{\circ}$ and $462^{\circ} \mathrm{C}$, respectively, the liquid being at $460^{\circ}$ and $472^{\circ} \mathrm{C}$, and the foam and vapor just prior to ignition reached over $600^{\circ}$ and $645^{\circ} \mathrm{C}$, as measured by a thermocouple held just above the liquid. The self-ignition of vinyl chloride-acetate was usually indicated, as stated before, by glow of carbonized portions inside the spongy shell; however, at higher air temperatures these glowing portions ignited gases developed in the incompletely carbonized mass. At an air temperature below $340^{\circ} \mathrm{C}$, polystyrene developed such an amount of incombustible gas during about the first 5 minutes that the pilot flame could not be kept lighted. However, at the next stage of decomposition this effect disappeared, and the burning of the pilot flame became normal. At an 
air temperature of $345^{\circ} \mathrm{C}$ gases that developed during the second stage could be ignited by the pilot flame after about $13 \mathrm{~min}$, and at $488^{\circ} \mathrm{C}$ they were self-ignited after $5.5 \mathrm{~min}$. It is interesting to note that the temperature of the liquid polystyrene always was below the air temperature and when self-ignition occurred, it was only $400^{\circ} \mathrm{C}$.

The ignition characteristics of polytetrafluoroethylene were determined only approximately, because of the limited size of the sample then available.

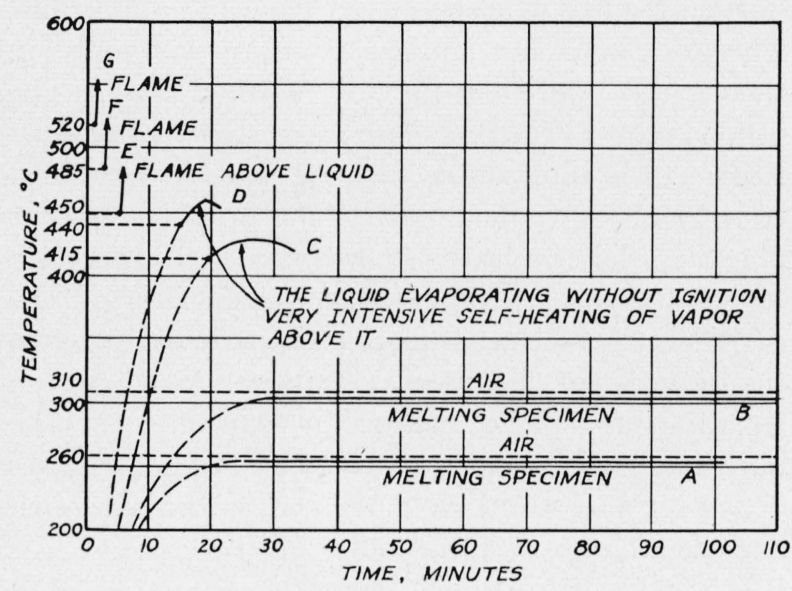

Figure 6. Time-temperature curves for methyl metacrylate $(a)$.

Curves A to $\mathrm{D}$ for nonignition reaction, curves $\mathrm{E}$ to $\mathrm{G}$ for self-ignition reaction.

\section{Ignition Characteristics of Reinforced Thermo- setting Materials}

The plastics of the thermosetting group usually changed their shape slightly because of a slow process of blistering and carbonization at temperatures below that of self-ignition. When these materials were heated at or near the ignition temperature for an appreciable time, the plastic resin evaporated or carbonized, but the asbestos and glass fabrics remained in layers. On the other hand, combustible fillers, such as paper or cotton fabrics, usually carbonized slowly into a more or less uniform mass with blisters on the surface. If, at comparatively high temperatures, then the glow started at the edges and corners or in the cracks. At still higher temperatures, the decomposition proceeded faster and the gases were selfignited by the exothermic reaction with the passing air.
The ignition characteristics of plastics of the phenolic laminate group varied considerably with the type of filler, as shown in the second part of table 2. The flash temperature varied from $300^{\circ}$ to $540^{\circ} \mathrm{C}$. Glow was observed only if paper or cotton cloth fillers were present. Glow in other phenolic materials was not sustained after removal of the specimen from the furnace, in spite of very intense self-heating, which sometimes produced a temperature of $600^{\circ} \mathrm{C}$. The lowest self-ignition temperature, characterized by a flickering flame, varied from $430^{\circ}$ to $580^{\circ} \mathrm{C}$., depending upon the type of the filler. The combustion of these fillers was usually slow and not sustained after removal of the specimen from the apparatus.

The ignition characteristics of materials of the melamine group also varied with the type of filler, as shown in table 2. The rate of oxidation of mineral-filled melamine was found very sensitive to airflow and size of specimen, as shown on the curves $F, G$, and $H$ in figure 7 , particularly in the region of glow. The specimens of normal size did not reach the state of glow with the different rates of air flow, marked on the timetemperature curves corresponding to initial air temperature of $368^{\circ}$ and $384^{\circ}$ C. However, the specimens of double that size were found glowing at $350^{\circ}, 355^{\circ} \mathrm{C}$, and higher temperatures, with practically the same variations in the air flow. The size of the cotton-cloth melamine laminate submitted for test was sufficient for the determination of the self-ignition temperature only. Therefore, data on flash and glow temperatures were not developed for this material.

Glass-cloth melamine laminate (a) was the most heat-resistant of the plastics tested. In spite of the evolution of dense smoke, the oxidation reaction was so weak that up to a temperature of $450^{\circ} \mathrm{C}$ the self-heating did not exceed $15 \mathrm{deg} \mathrm{C}$ above the air temperature. In the region of $500^{\circ} \mathrm{C}$, the temperature of the mass of melamine laminate increased about $100 \mathrm{deg}$ C above the air temperature, and the color of the mass became a dull red. Dense smoke, in which the odor of ammonia was predominant, usually disappeared in $4 \mathrm{~min}$. The oxidation reaction in the gas evolved from the specimen at that time became so intense that the wires holding the specimen were heated to a bright red color, distinctly visible against the darker specimen and 


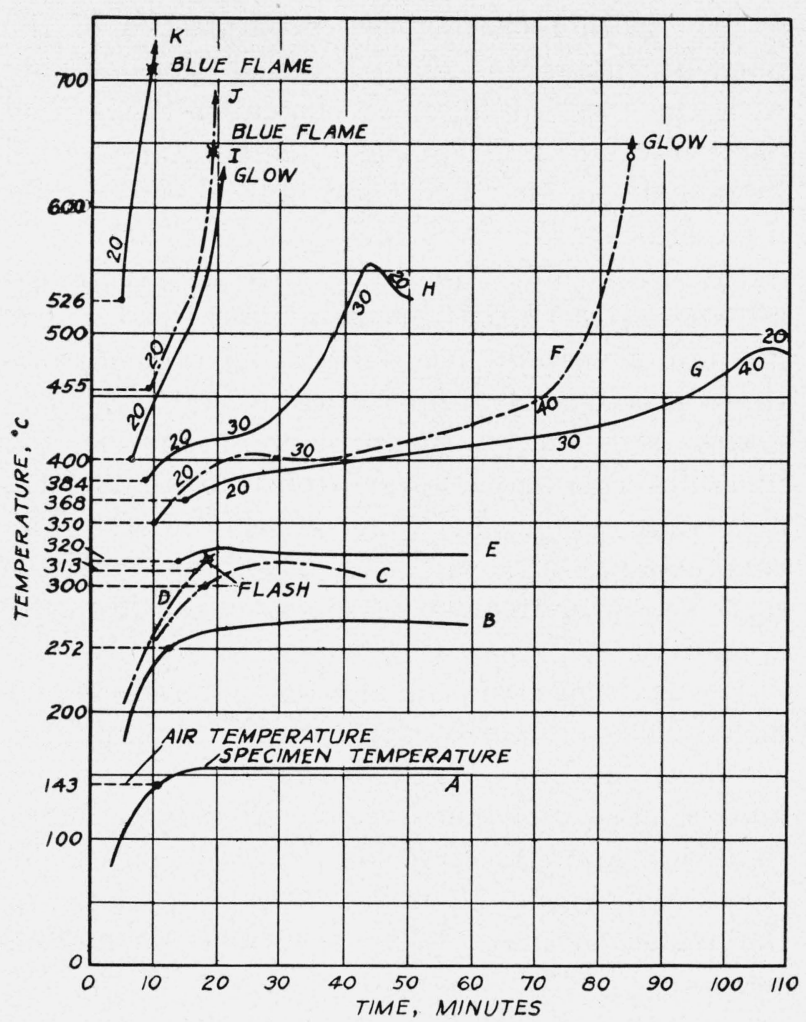

Figure 7. Time-temperature curves for mineral-filled melamine.

Curves $A, B, C, D, E, G$, and $H$ for nonignition reaction, curves $F, I, J$, and $K$ for self-ignition reaction. Figures on curves-air velocities in feet per minute, curves $F, G$, and $H$ are taken during adjustment of air flow.

_-

furnace wall. The intensity of self-heating in the melamine increased with air temperatures up to $660^{\circ} \mathrm{C}$, at which temperature a blue flame started to flicker over the darker surface of the specimen. The red color of the self-heated mass of material did not represent a state of sustained glow, because when the specimen was moved into a cooler portion of the furnace or was removed from the furnace entirely, the mass cooled rapidly.

The self-ignition temperature of this plastic is difficult to determine exactly because of the several different types of ignition that were observed. With careful adjustment of an optimum air flow, an occasional blue or red flame was observed for type (a) at an air temperature of $645^{\circ} \mathrm{C}$, a flickering of blue flame was observed at $662^{\circ} \mathrm{C}$, and a continued flaming at $673^{\circ} \mathrm{C}$. The lowest selfignition temperature was $645^{\circ} \mathrm{C}$. The ignition of gases by the pilot flame was obtained occasionally at $500^{\circ} \mathrm{C}$ and regularly at an air temperature of $544^{\circ} \mathrm{C}$. For glass cloth melamine laminate (b), self-ignition was occasionally observed at $623^{\circ} \mathrm{C}$ and the flash temperature at $475^{\circ} \mathrm{C}$.

The ignition characteristics of the polyester plastics were substantially the same. The flash temperature varied from $346^{\circ}$ to $394^{\circ} \mathrm{C}$ and the self-ignition temperature from $433^{\circ}$ to $488^{\circ} \mathrm{C}$. The self-ignition was characterized by mild explosion of gases developed from the material, or by an audible flash of gases without destructive effect. The combustion of these materials varied quite appreciably: glass-cloth laminate type (d) burned readily when removed from the apparatus, whereas types (c) and (g) burned well only in the furnace and then for only a short time. The other materials of this class were slightly combustible. It is interesting to note that the combustible gases developed from some of the polyester plastics were relatively heavy, and therefore settled to the bottom of the furnace during the early states of decomposition, particularly when the rate of air flow was very low. Self-ignition usually took place below the specimen in the bottom of the furnace, and burning of these gases in the furnace continued even after the specimen had been carefully lifted out.

Both types of glass-cloth silicone laminate had about the same ignition characteristics. These withstood heating very well up to $450^{\circ} \mathrm{C}$. Appreciable self-heating $\left(115^{\circ} \mathrm{C}\right)$ was observed at $540^{\circ} \mathrm{C}$. Flammable gases were developed at a temperature of $490^{\circ} \mathrm{C}$ for this plastic of type (b) and at $527^{\circ} \mathrm{C}$ for type (a). Such high flash points for gases seemed to be caused by the development of a noncombustible gas during an early stage of the decomposition of the material. This gas extinguished the pilot flame during the first $5 \mathrm{~min}$. of the reaction. The self-ignition of the gases was irregular and was first observed at air temperatures of about $564^{\circ} \mathrm{C}$ and then only after 5 -min lag, when the contamination of the combustible gases had been sufficiently reduced. At an air temperature of about $600^{\circ} \mathrm{C}$, self-ignition became more regular, and the time lags varied from 2 to 3 min. During the next 3 min the plastic burned with long orange flames.

\section{Reproducibility of Test Results}

The reproductivity of the ignition temperature values of plastics as determined in the present 
apparatus depends upon two major factors: one is uniformity of chemical composition and physical state of the plastics from which the specimens are taken; and the other is the sensitivity of the test method and the apparatus to the ignition characteristics of the material. The first factor was substantially constant for most of the plastic materials when tested and for a long time subsequently. An exception was found in cellulose nitrate, which sometimes changes under the action of sunlight and temperature. The ignition characteristics of some plastics, such as methyl methacrylate, vinyl chloride-acetate, and a few others (bearing the same names) varied with the manufacturer's lot or with their purity.

The sensitivity of the constant-temperature test method to the ignition properties characteristics of the material is high, owning to the fact that the temperature in the whole apparatus can be stabilized in advance and kept substantially constant during the test. The temperature and rate of air flow are under good control. The reproducibility of the results depends mainly upon the accuracy of the test procedure and the interpretation of the observed evidence of ignition, i. e., upon the following three factors: (1) The positioning of the specimen in the region of uniform temperature in the furnace tube (middle position); (2) correct selection of the optimum air flow for the most favorable rate of temperature rise in the reacting mass; and (3) careful bracketing of the temperatures that correspond to the types or stages of ignition, such as: explosion, flash, flame, glow, cold flame, or luminescence.

The bracketing of the lowest ignition temperature is usually made in the manner shown in table 4 , with five or more determinations within the region of the boundary between ignition and nonignition zones in order to secure the desired temperature range, which is usually between 2 and $5 \mathrm{deg} \mathrm{C}$. This range depends upon the required accuracy and the available time, since the time lag in this region may vary from a few minutes to a few hours.

TABLE 4. Determination of the lowest self-ignition temperature

\begin{tabular}{|c|c|c|c|c|c|c|c|c|c|c|c|c|c|c|c|}
\hline \multicolumn{4}{|c|}{ Methyl methacrylate } & \multicolumn{4}{|c|}{ Vinyl chloride acetate } & \multicolumn{4}{|c|}{ Paper phenolic } & \multirow{2}{*}{\multicolumn{2}{|c|}{$\begin{array}{l}\text { Mineral filler } \\
\text { melamine }\end{array}$}} & \multirow{2}{*}{\multicolumn{2}{|c|}{$\begin{array}{l}\text { Glass cloth } \\
\text { polyster }\end{array}$}} \\
\hline \multicolumn{2}{|r|}{ (a) } & \multicolumn{2}{|r|}{ (b) } & \multicolumn{2}{|c|}{ (a) clear } & \multicolumn{2}{|c|}{ (b) yellowish } & \multicolumn{2}{|r|}{ (a) } & \multicolumn{2}{|r|}{ (b) } & & & & \\
\hline $\begin{array}{l}\text { Tem- } \\
\text { pera- } \\
\text { ture }\end{array}$ & Evidence & $\begin{array}{l}\text { Tem- } \\
\text { pera- } \\
\text { ture }\end{array}$ & Evidence & $\begin{array}{l}\text { Tem- } \\
\text { pera- } \\
\text { ture }\end{array}$ & Evidence & $\begin{array}{l}\text { Tem- } \\
\text { pera- } \\
\text { ture }\end{array}$ & Evidence & $\begin{array}{l}\text { Tem- } \\
\text { pera- } \\
\text { ture }\end{array}$ & Evidence & $\begin{array}{l}\text { Tem- } \\
\text { pera- } \\
\text { ture }\end{array}$ & Evidence & $\begin{array}{l}\text { Tem- } \\
\text { pera- } \\
\text { ture }\end{array}$ & Evidence & $\begin{array}{l}\text { Tem- } \\
\text { pera- } \\
\text { ture }\end{array}$ & Evidence \\
\hline${ }^{\circ} \mathrm{C}$ & & ${ }^{\circ} \mathrm{C}$ & & ${ }^{\circ} \mathrm{C}$ & & ${ }^{\circ} \mathrm{C}$ & & ${ }^{\circ} \mathrm{C}$ & & ${ }^{\circ} \mathrm{C}$ & & ${ }^{\circ} \mathrm{C}$ & & ${ }^{\circ} \mathrm{C}$ & \\
\hline 550 & Flash ...... & 517 & Flash.... & 580 & Flash ..... & 500 & Flash..... & 463 & Flash ..... & 475 & Flash.... & 572 & Flash ..... & 488 & Flash. \\
\hline 510 & Flame..... & 470 & Flame ..... & 564 & Flame ..... & 475 & Flame..... & 442 & Flame & 469 & ... do do...... & 545 & $\begin{array}{l}\text { Orange } \\
\text { flame. }\end{array}$ & 470 & Flame. \\
\hline 470 & $\ldots \mathrm{do} \ldots$ & 464 & $\ldots$ do $\ldots$ & 560 & $\ldots$ do & 440 & ... do ... & 433 & $\ldots \mathrm{do}$ & 467 & Flame... & 532 & Blue flame_ & 466 & Flame. \\
\hline 453 & $\ldots$ do $\ldots$ & 462 & ... do do ....... & 557 & $\ldots$.......... & 435 & ... do d........ & 430 & $\ldots$ do & 468 & Glow & 455 & $\ldots$.... do _...... & 462 & Do. \\
\hline 450 & $\ldots$ do $\ldots . . . . .$. & 460 & No igni- & 553 & Glow & 432 & Glow & 427 & Glow _- & 463 & _._. do _. & 453 & Glow & 463 & Glow. \\
\hline 448 & No ignition & 458 & ... do & 550 & _._. do _....... & 428 & _.. do do....... & 423 & $\ldots$. do _....... & 418 & ... do & 408 & _._. do _....... & 558 & Do. \\
\hline 445 & $\ldots$ do $\ldots . . . . .$. & 455 & $\ldots$. do & 420 & $\ldots$ do $\ldots \ldots$ & 382 & $\ldots$ do & 366 & $\ldots$ do $\ldots . . .$. & 350 & ... do do ..... & 355 & $\ldots$ do $\ldots . . . .$. & 404 & Do. \\
\hline 440 & ... do ........ & 450 & .._do do........ & 377 & $\ldots \mathrm{do} \ldots \ldots$ & 355 & $\ldots$............ & 310 & $\ldots \mathrm{do} \ldots \ldots$ & 344 & ... do & 350 & $\ldots$.... do _...... & 400 & Do. \\
\hline 440 & ... do _ & . & $\ldots$ & $\begin{array}{l}375 \\
370 \\
361\end{array}$ & $\begin{array}{c}\text { No igni- } \\
\text { tion. } \\
\text { do }\end{array}$ & $\begin{array}{l}353 \\
350 \\
340\end{array}$ & $\begin{array}{c}\text { No igni- } \\
\text { tion. } \\
\text { do do }\end{array}$ & $\begin{array}{l}307 \\
303 \\
298\end{array}$ & $\begin{array}{l}\text { No igni- } \\
\text { tion. } \\
\text { _do do }\end{array}$ & $\begin{array}{l}342 \\
338 \\
320\end{array}$ & $\begin{array}{c}\text { No igni- } \\
\text { tion. } \\
\text {-. do do }\end{array}$ & $\begin{array}{l}346 \\
344 \\
312\end{array}$ & $\begin{array}{l}\text { No igni- } \\
\text { tion. } \\
\text {... do do }\end{array}$ & $\begin{array}{l}398 \\
392 \\
360\end{array}$ & $\begin{array}{l}\text { No igni- } \\
\text { tion. } \\
\text { Do. } \\
\text { Do. }\end{array}$ \\
\hline
\end{tabular}

In table 4 only typical results are given, and many practically identical results observed during the tests are omitted. In some cases a nonignition state was observed 1 or 2 deg. C above the lowest self-ignition temperature, owing to accidental variation of test conditions. When the evidence of the ignition is clearly defined (as with cellulose nitrate and acetate, methyl methacrylate, and other thermoplastic materials) the results are closely reproducible. For example, a sample of methyl methacrylate plastic of type (a) was tested in October 1946 and retested in March and December 1947; the results were $450^{\circ}, 451^{\circ}$, and $450^{\circ} \mathrm{C}$. In contrast, methyl methacrylate 
of another shipment, type (b) had an ignition temperature of $462^{\circ} \mathrm{C}$. Yellowish vinyl chlorideacetate, type (b) was tested first in October 1946 and retested in February 1948, with the same value, $435^{\circ} \mathrm{C}$, which differed from the value $\left(557^{\circ} \mathrm{C}\right)$ for the clear type (a).

In those cases where the evidence is not clearly defined owing to a gradual change of intensity and color of the flame from a steady orange to a flickering blue, or to the appearance of flame at the end of the glowing period, the reproducibility of results depends upon the type of observed evidence. For example, the flash of the paper phenolic laminate was observed at $467^{\circ} \mathrm{C}$ after a 4-min lag; another specimen of the same sample glowed at $467^{\circ} \mathrm{C}$, and a weak flickering flame appeared only after 16-min lag. This difference was caused by sudden exposure of a noncarbonized portion of the specimen to hot air through the opening of a crack or the separation of layers of the specimen. However, the change between glow and nonglow states was defined more clearly at $344^{\circ} \mathrm{C}$, a value reproduced at other times.

The determination of the ignition state was more difficult with glass-cloth melamine laminate. In the absence of glow, the intensity of ignition gradually diminished from a bright flash at $673^{\circ} \mathrm{C}$ to a blue flame at $662^{\circ} \mathrm{C}$, which did not appear at all at $650^{\circ} \mathrm{C}$. However, the flame was observed in two of five specimens at $645^{\circ} \mathrm{C}$, but in none of the five at $630^{\circ} \mathrm{C}$. No explanation of this uncertainty of behavior is offered, but it could be caused by the presence of ammonia gas, which might have interfered with the ignition.

The reproducibility of the test results depends upon careful technique and accuracy of observation, as much as upon the apparatus and the principles involved.

\section{Ignition by Hot Surface}

Early determinations of the ignition temperature of plastics were often made by contact with hot surfaces. Basically, in the hot-surface methods, the surface is only a medium for the transmission of heat to the specimen, because the hot surface does not participate in the oxidation that usually causes ignition. The essential element in the ignition is the oxygen of the air, the temperature of which is usually considerably below that of the hot surface, particularly if the latter is not within a uniformly heated furnace. Moreover, in most cases, the ignition of plastics occurs because of intense oxidation of the gaseous components evolved during the process of heating. This process requires a time lag, which varies from hours to fractions of a second, depending upon the ambient air temperature. The air-temperature gradient from a vertical hot surface exposed to the atmosphere, as our experiments showed, varies considerably with the distance from the surface. The temperature drop in the first $1 / 8$-in. (3-mm) zone is from $150^{\circ}$ to $200^{\circ} \mathrm{C}$ when the temperature of the hot surface is $600^{\circ} \mathrm{C}$. These results are in agreement with Kennard Work [9]. Combustible gaseous products from plastics, turbulently moving along the surface within the zone, usually have only a few seconds in which the oxidation reaction may be accelerated to cause ignition. Therefore, for this limited time lag the average air temperature within the $1 / 8-i n$. (3-mm) zone must be much higher to cause ignition than in a uniformly heated furnace with an unrestricted time lag. Hence, ignition by contact with a hot surface occurs only at higher temperatures than are required for ignition in uniformly heated air.

The hot-surface apparatus used in these studies consisted of a $1 / 4-$ in. $(0.6-\mathrm{cm})$ steel plate, heated by coiled resistance wire imbedded in the grooves of a refractory plate attached to the back of the steel plate. All sides of the assembly, except the front, were heavily insulated by asbestos wool mixed with vermiculite. The temperature of the exposed front vertical surface of the "hot plate" was indicated by a thermocouple junction imbedded in the plate. The specimen was usually held in contact with the vertical hot surface about 5 min, or until ignition took place, which might occur during the first 1 or $2 \mathrm{~min}$. The temperatures of the hot plate at which different plastics were ignited are given in the fifth column of table 2. With the exception of cellulose nitrate and cotton-fabric phenolic laminate, most plastics ignited only at plate temperatures of $600^{\circ} \mathrm{C}$ or higher. Three thermosetting plastics, although ignited by other methods as shown in table 2 , did not ignite with the maximum hot surface temperature of $750^{\circ} \mathrm{C}$.

These results show that the "hot-surface-contact method" is not as suitable for indicating the lowest temperature of ignition, i. e. the fire-hazard of a material, as is the constant-air-temperature method. 


\section{Summary}

A new method and apparatus were developed from consideration of the principles of ignition, as explained in section II. The ignition characteristics and thermal behavior of materials were determined in this apparatus under well-controlled conditions.

Operation of this apparatus by the constant-airtemperature method is simple at temperatures up to $800^{\circ} \mathrm{C}$. The air temperature around the specimen, in spite of the readily sustained constant temperature of the wall, is very sensitive to the velocity of air flow and to the heat radiated from the specimen during the exothermic reaction. The first factor can be controlled with an approximately optimum air flow, adjusted for a favorable rate of ignition as indicated by the rate of temperature rise. The second factor has no appreciable effect on the results if other temperatures in the apparatus remain constant. The effect of the second factor can be minimized, if necessary, either by shielding the thermocouple $\left(T \mathrm{~h}_{2}\right)$ that indicates the temperature of air approaching the specimen, or by shifting it farther away from the specimen.

The lowest values of the temperatures defined as "flash" and "self-ignition" were selected to indicate the fire hazards of the plastics. The flash temperatures for most of the plastics listed in tables 1 and 2 , are in the range from $280^{\circ}$ to $525^{\circ} \mathrm{C}$, with the exception of cellulose nitrate, which flashes at $141^{\circ} \mathrm{C}$. The self-ignition temperatures for 17 of the 27 specimens tested lie in the range from $430^{\circ}$ to $500^{\circ} \mathrm{C}$. Cellulose nitrate, however, self-ignites at $141^{\circ} \mathrm{C}$, whereas specimens of glass-cloth melamine laminate ignited at $623^{\circ}$ and $645^{\circ} \mathrm{C}$. The values of these temperatures were found to be reproducible to within 1 or $2 \mathrm{deg} \mathrm{C}$.

The effect of heat on the physical state of various plastics is illustrated in figures 8,9 , and 10 . Of particular interest is the ability of a material to retain its transparency and resist discoloration and carbonization. The transparency of most of the plastics in the thermoplastic group, as shown in figures 9 and 10, disappears in the range of $130^{\circ}$ to $250^{\circ} \mathrm{C}$, although cellulose nitrate loses its transparency at $105^{\circ} \mathrm{C}$. For the reinforced thermosetting plastics, discoloration and carbonization depend not only upon the temperature, but also upon the duration of heating.

The specimens shown in figures 8,9 , and 10 were chosen at random and do not necessarily represent uniform steps in the process of degradation. The temperature and time data have only relative and incidental significance. The examples in figure 10 show that the most heat-resistant plastics were those consisting of glass-cloth with silicone, melamine, or polyester resins. These withstood heating to $300^{\circ} \mathrm{C}$ for approximately 1 $\mathrm{hr}$ without appreciable discoloration. The thermoplastic group, with the exception of methyl methacrylate (6), did not withstand even $200^{\circ} \mathrm{C}$ without considerable bubbling or melting.

The new method for the determination of ignition characteristics of materials is the first major step in evaluating the ignition properties of a material in terms of the temperature and controlable condition that may be as important as for other physical properties such as density, conductivity, etc.

\section{References}

[1] H. N. Stokes and H. C. P. Weber, effect of heat on celluloid and similar materials, Techn. Pap. BS T98 (1917).

[2] J. Delmonte and M. A. Azam, Ignition points of plastic material, Mod. Plastics 20, No. 6, 88 (Feb. 1943).

[3] E. M. Schoenborn and D. S. Weaver, Ignition temperature of rigid plastics, ASTM Bull. No. 146, 80 (May 1947).

[4] N. P. Setchkin, Discussion of paper on the ignition temperature of rigid plastics, ASTM Bull. No. 151, 66 (Mar. 1948).

[5] J. A. Gale, R. W. Stewart, and J. B. Peters, ASTM Bull. No. 131, 23 (Dec. 1944).

[6] L. B. Berger, J. P. Gale, and others, Toxicity and flame resistance of thermosetting plastic, Bureau of Mines R 14134 (Oct. 1947).

[7] C. R. Brown, The determination of the ignition temperature of solid materials (The Catholic Univ. of America, Washington, D. C., 1934).

[8] N. P. Setchkin and S. H. Ingberg, The criterion of the incombustibility of materials, ASTM Proc. 45, 866 (1945).

[9] R. B. Kennard, An optical method for measuring temperature distribution and convective heat transfer, BS J. Research 8, 787 (1932) RP452. 


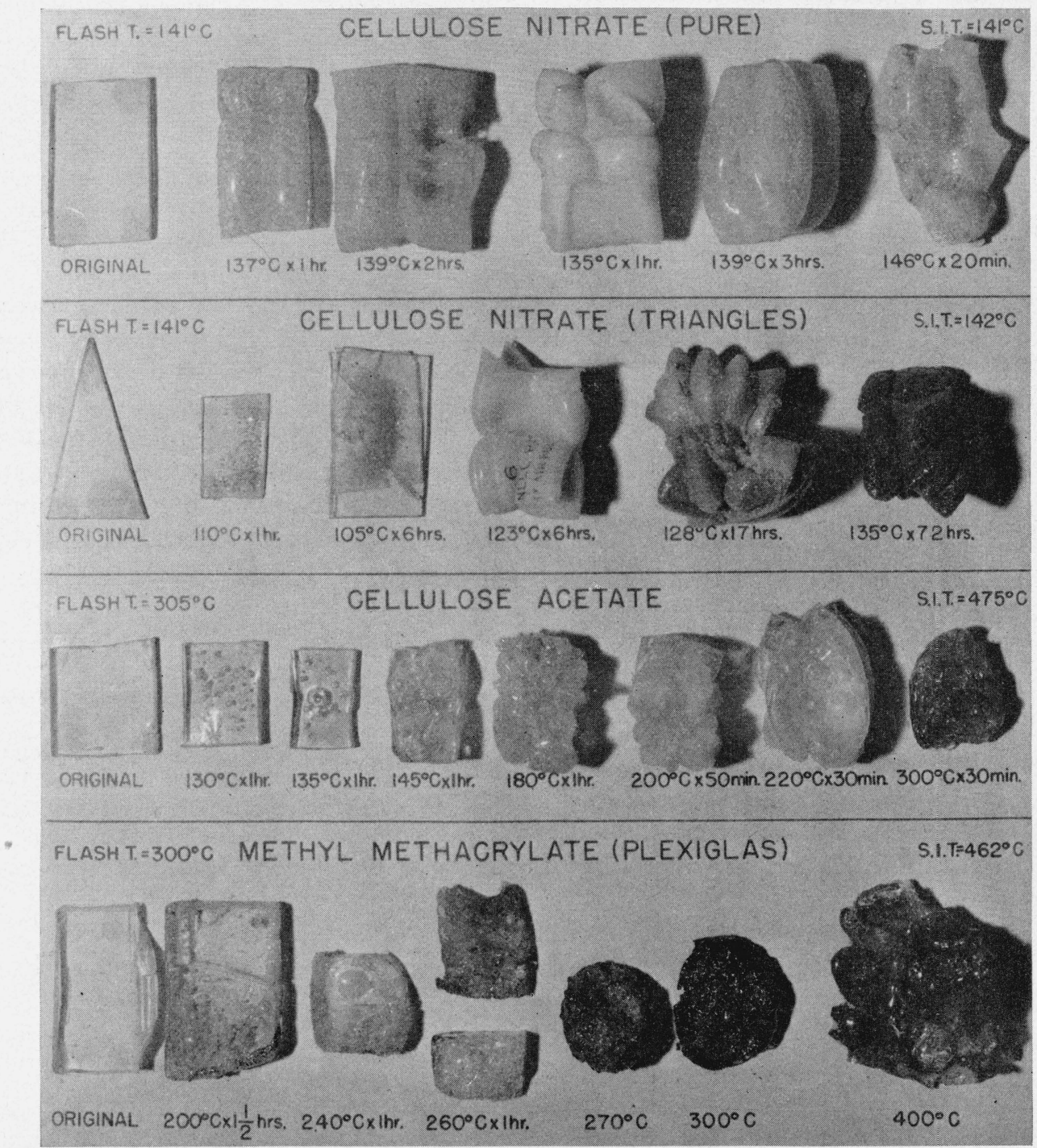

Figure 8. Appearance of plastics after being heated at indicated temperatures for designated period. 


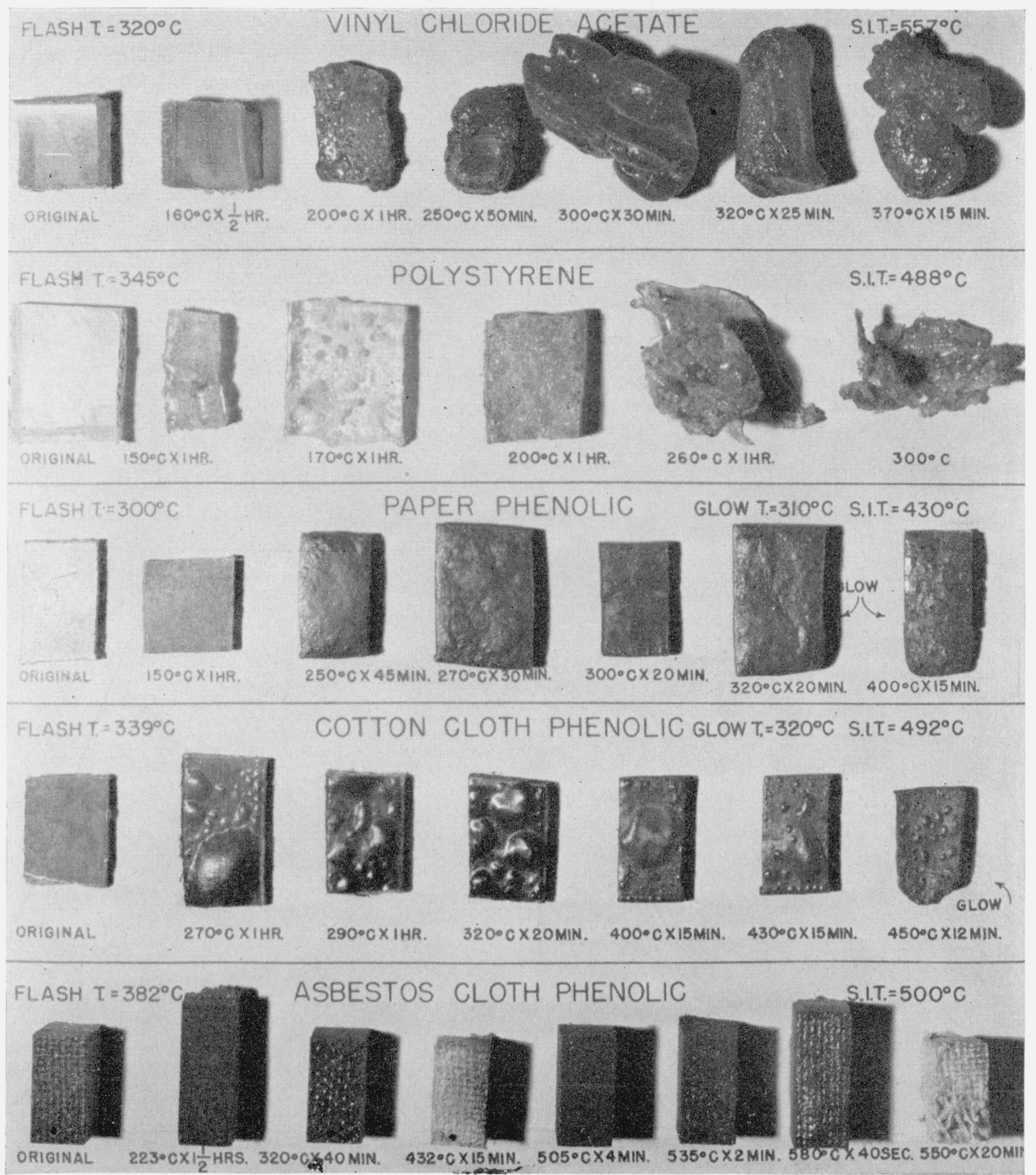

FiguRE 9. Appearance of plastics after being heated at indicated temperatures for designated period. 


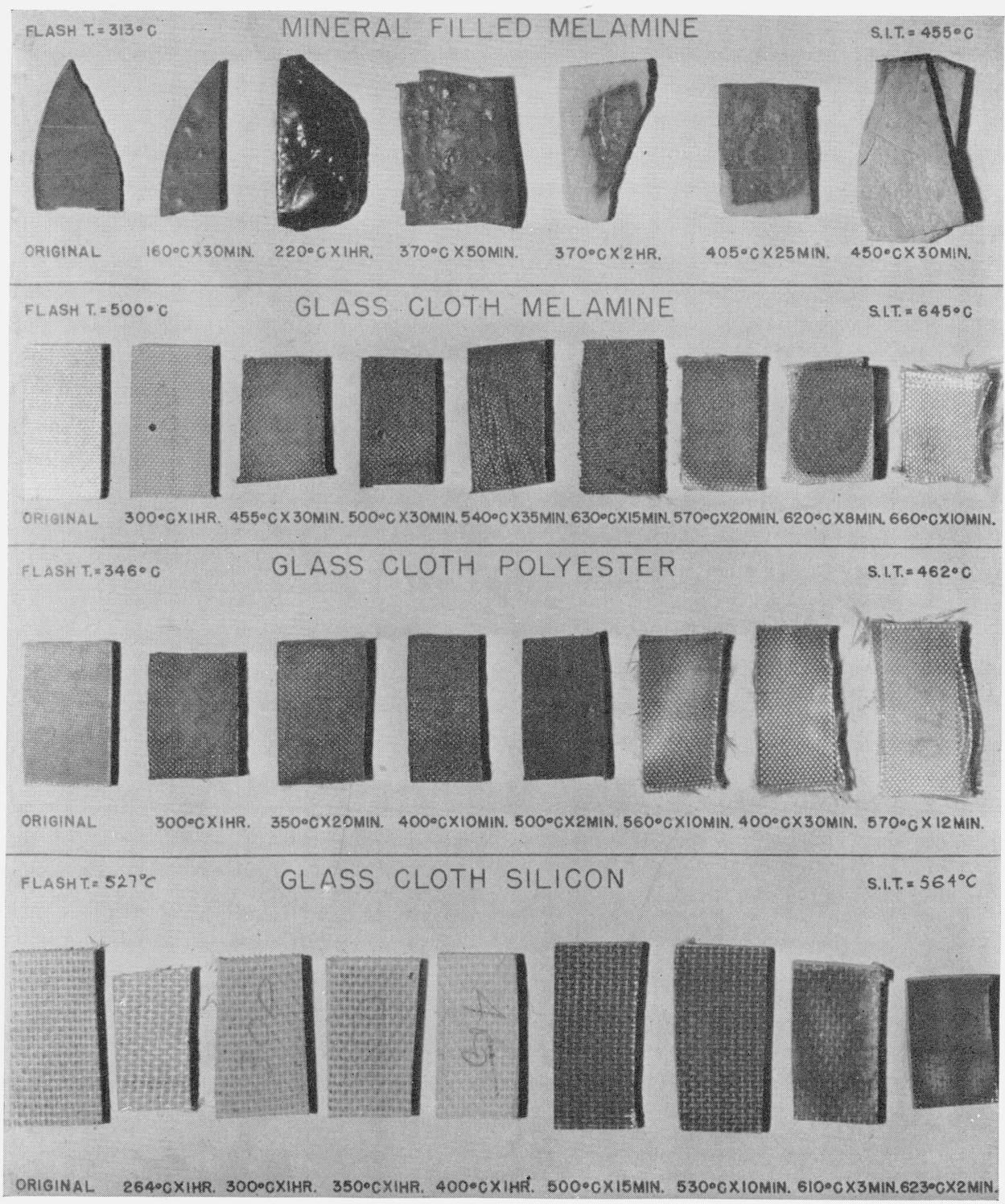

FIGURE 10. Appearance of plastics after being heated at indicated temperatures for designated period.

Washington, March 16, 1949. 